\title{
Effect OF Dietary Alpha-Linolenic Acid On Reproductive Performance And The Semen Characteristics Of Rabbit Males
}

\author{
Baiomy, A.A ${ }^{1}$ and H. H. M, Hassanien ${ }^{2 *}$. \\ ${ }^{1}$ Animal and Poultry Prod. Dep. Faculty of Agriculture, South Valley University \\ ${ }^{2}$ Animal and Poultry Prod. Dep. Faculty of Agriculture, Beni--Suef University \\ *Corresponding author: e-mail: hb_hossam10@yahoo.com
}

Received on: 25/2/2020

Accepted on: 5/4/2020

\begin{abstract}
This study was carried out in the Animal Production Experimental farm Faculty of Agriculture, South Valley University, during the period from January to April 2018. The aim of the present study was to evaluate the effect of different dietary level of a-linolenic on the semen characteris tics of the male rabbits of New Zealand White. The aimof the present study was to evaluate the effect of differentdietary level of a-linolenic on the semen characteris tic s of the male rabbits of New Zealand White. Used Thirty New Zealand White rabbit males were divided into three groups. First g ro up; males were fed control ration, second group males were fed tested one ration; (supplemented with $4 \%$ extruded flaxs eed) and third group males were fed tested ration two; (supplemented with $6 \%$ extruded flaxseed). The reproductive performances and semen characteris tics of the male rabbits of NewZealand White were evaluated. The diet affected many seminal traits and the males of control group showed the lowest values of live cells and spermatozo a concentration. The linoleic (18:3, n-3) fatty acids in the diet (supplemented with $4 \%$ or $6 \%$ extruded flaxs eed) was to increased signific antly their levels within the spermatozoa and to have extensive beneficial effects on parameters of s permatozoa function and therefore male fertility in the New Zealand Whiterabbit males .
\end{abstract}

KEYWORDS: Reproductive performance; rabbit spermatozoa; n-3 fatty acids.

\section{INTRODUCTION}

There is an overwhelming preponderance of linoleic (18:3, n-3) in proprietary feeds of domestic farm animals. Other fatty acids of the n- 6 series are notable by their virtual absence. That such a predominance of linoleic acid may not always be wholly beneficial to the well-being and health of the animal through effects upon tissue fatty acid composition and aspects of metabolism is now being asked. With such a high-profile presence of long chain polyunsaturated fatty acids of the $n-3$ series in mammalian sperm lipids, it is suggested that the alteration of the current fatty acid profile of animal proprietary feeds towards increasing levels of acids of the $n-3$ series may be highly relevant to the ontogeny of the characteristic fatty acid profiles and subsequent function of the sperm. The need exists to extend the life of semen for a fresh delivery service and enhance the ability to maintain spermatozoa function during the following cryoscopic storage in all farm animal species. All animal species' spermatozoa have high concentrations of polyunsaturated phospholipids. In mammalian species e.g. the bull, buffalo, ram and rabbit males the substantial level of polyunsaturated present is characteristically dominated by the alphalinolenic acid (18:3, n-3) series .Polyunsaturated fatty acids of $n-3$ series are essential for the reproductive activity representing about $30-50 \%$ of total amount in the membrane of mammal spermatozoa (Poulos et al., 1973) and contributing to regulate fluidity and acrosome responsiveness. Many authors (Blesbois et al., 1997; Rooke et al., 2001), reported that an increase of $n-3$ in the sperm membrane by dietary supplementation resulted in improved spermatozoa characteristics. However, such enrichment simultaneously increases the susceptibility of spermatozoa to peroxidation, which is one of the major causes of male infertility (Jones et al., 1979; Aitken et al., 1993). The lipid composition of the spermatozoan membrane may be a major determinant of motility, cold sensitivity and a wide selection of factors associated with overall viability within fresh ejaculates or stored ejaculates maintained at $-196 \mathrm{c}$ degree for artificial insemination. Thus, to ensure suitable sperm membrane function it is crucial to maintain an equilibrium between the level of unsaturation and the oxidative stability of semen (Comhaire et al., 2000; Castellini et al., 2003). Flaxseed oil are quite a few different herbs that males can take to increase their fertility. One such herb which plays a role in promoting male fertility is flaxseed oil. The ingredients within flaxseed oil help 


\section{Scientific Journal of Agricultural Sciences 2 (1): 50-54, 2020}

to keep the sperm healthy and may also help with regard to male impotence. The aim of the present study was to evaluate the effect of different dietary level of a-linolenic on the semen characteristics of the male rabbits of New Zealand White.

\section{MATERIALS AND METHODS}

This study was carried out in the Animal Production Experimental farm Faculty of Agriculture, South Valley University, during the period from January to April 2018.

\subsection{Animals :-}

A total of 30 male rabbits of New Zealand White breed were used. After weaning (at four weeks of age), the rabbits were housed in individual cages (with a photoperiod of 16 hours light: 9 hours dark and temperatures ranging from ( $18.6 \mathrm{c}$ to $24.4 \mathrm{c})$ in the same room, receiving ration and $w$ ater ad libitum .

\subsection{Diets :-}

Animals are fed ad libitum with commerc ial rabbit pellets. Three groups of 10 New Zealand White male rabbits were used. Each group was further divided and fed ad libitum as follows: T1 standard diet (Control group);

T2 standard diet+4 \% extruded flaxseed(Sec ond group fed tested one ration);

T3 standard diet $+6 \%$ extruded flaxseed (Third group fed tested two ration) ;

Extruded flaxseed $(2630 \mathrm{kcal} \mathrm{DE} / \mathrm{kg}$ ) contained about $56 \%$ of C18:3n-3 (Castellini et al., 2003) as described in Table1. Chemical analyses of diets were done according to A.O.A.C. methods (2015). Fatty acids were determined on lipids extracted from samples of about $5 \mathrm{~g}$ in a homogeniser with $20 \mathrm{~mL}$ of 2:1 chloroform: methanol (Folch et al., 1957).

\subsection{Semen collection and analysis}

At five months of age males started the training period with artificial vagina. One ejaculated was collected per male and week. At six months of age they started production period. During7 weeks, weekly two ejaculates per male and week were collected, with an interval of 30 minutes between them. All ejaculates were stored at $37 .^{\circ} \mathrm{C}$ in a water bath until evaluation, non-later than 15 minutes after collection. Volume and $\mathrm{pH}$ of the ejaculate were determined by using a graduated tube and a $\mathrm{pH}$-meter 507 Crison, respectively. Immediately after collection, the amount of ejaculate $(\mathrm{ml})$ and the spermatozoa concentration (number of sperms $\mathrm{ml}$ ) were recorded by using respectively a graduated tube and an haemocytometer . Mass motility $(\mathrm{Mm})$ was assessed in a subjective scale from1 to 5, using aliquots (10.1) of the raw semen and a light microscope (Nikon) at x10.

\subsection{Statistical analyses}

Analysis of variance was carried out using SAS (2011), and the treatment means (spermatozoa mass volume and volume of ejaculate) compared by the tes $t$ of Duncan (1955).

\section{RESULTS AND DISCUSSION}

The chemical composition and the nutritional value of the diets (Table 2) were consistent with the standard requirements for rabbits (DE Blas and Wiseman, 1998).

The diets differed mainly for the fatty acid profile (Table 2): control diet showed high percentages of MUFA and PUFAn-6; whereas, as expected, Treatment diet had higher level of C18:3n-3 and n$3 / \mathrm{n}-6$ ratio. The diet affected many seminal traits: the control males showed the lowest values of live cells and spermatozoa concentration (Table 3 ).

Such results are consistent with the hypothesis, verified in other studies (Castellini et al., 2003; Conquer et al., 2000), that n-3 supplementation increases the phospholipid into spermatozoa and modifies the fatty acid profile of membrane. Presumably, this n-3 enrichment occurred mainly in the tail (Connor et al., 1998) and thus the increase of sperm velocity and ALH would be explained by the higher flexibility of tail. The higher fluidity and functionality of tail membrane (Ducci et al., 2002), is also suggested by the better reaction of LNA spermatozoa to hyposmotic solution (HOS). The diet also affected the oxidative status of semen: LNA group, although protected by higher amount of vitamin E, showed higher TBA-RS values both on fresh and stored semen samples. How ever, the lower antioxidant stability of LNA group did not determine any anomalous acrosomal behaviour and did not induce any changes to the response of spermatozoa to activating stimuli. In previous work (Castellini et al., $2003)$, the supplementation of refined fish oil (2\%) to rabbit males, beside the increase of LCP n-3 in spermatozoa membrane, resulted in a much higher TBA-RS value $(+30 \%)$ and acrosome reacted sperms $(+35 \%)$. Although in the case of the male rabbits these was a marked difference in the levels attainable within the spermatozoa of the long chain $n-3$ polyunsaturates, nevertheless effects on spermatozoa parameters were very positive. 22:6 (n-3) is an extensively available fatty acid (Castellini et al., 2003) That such a predominance of linoleic acid may not always be wholly beneficial to the well-being and health of the animal through effects upon tissue fatty acid 
Baiomy, A.A and H. H. M, Hassanien, 2020

Table 1. Formulation and chemical composition of the diets $(\mathrm{g} / \mathrm{kg})$

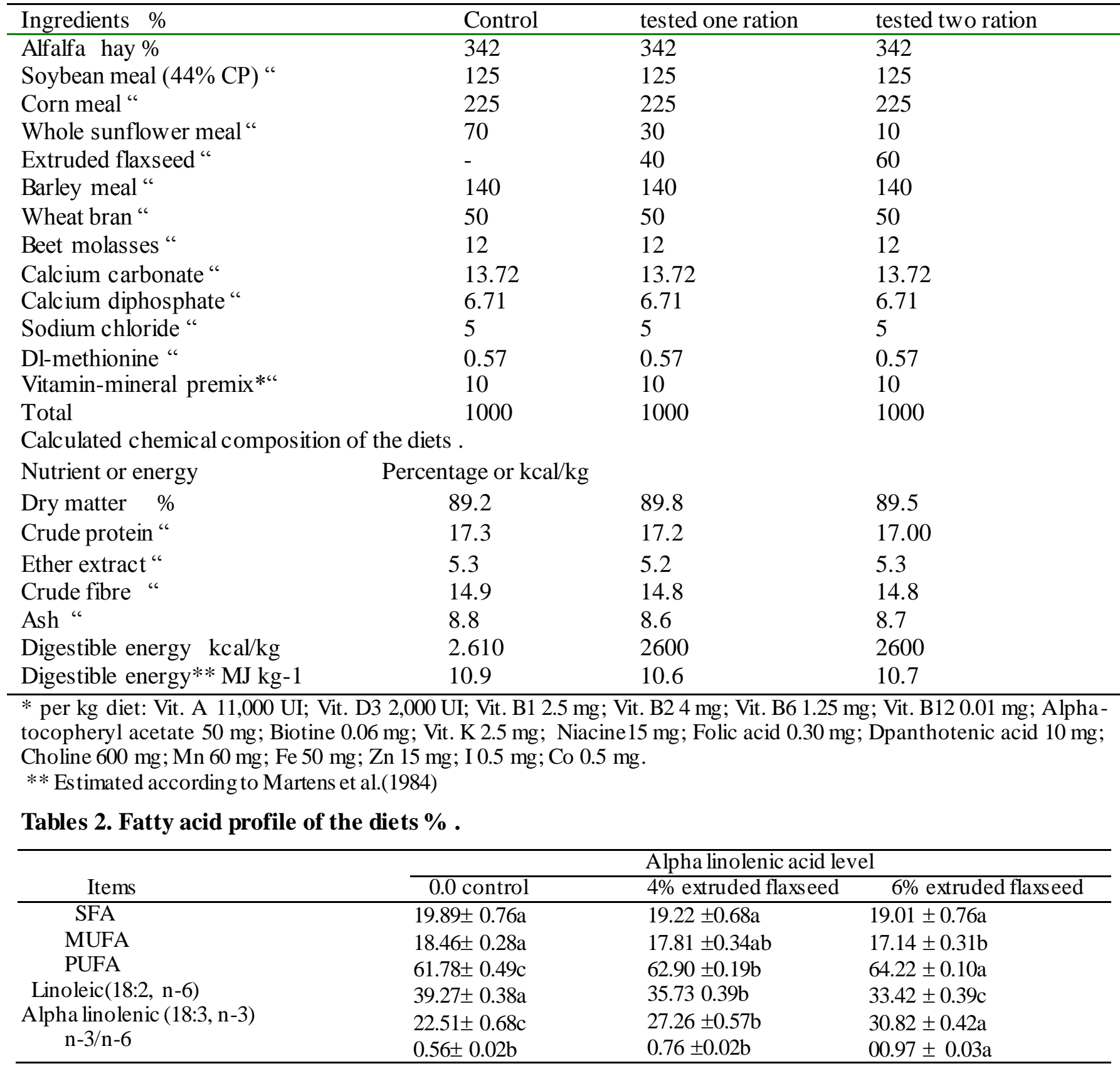

a,b means in the same row followed by the same letter are not sig nificantly different $(p>0.05)$.

Tables 3. Effect of dietary Alpha linolenic acid (18:3, n-3) supplementation semen characteristics of the male rabbits of New Zealand White.

\begin{tabular}{|c|c|c|c|}
\hline \multirow[b]{2}{*}{ Items } & \multicolumn{3}{|c|}{ Alpha linolenic acid level } \\
\hline & 0.0 control & $4 \%$ extruded flaxseed & $6 \%$ extruded flaxseed \\
\hline $\begin{array}{ll}\text { Ejaculate volume }(\mathrm{ml}) \\
\end{array}$ & $0.63 \pm 0.01 \mathrm{a}$ & $0.61 \pm 0.01 \mathrm{a}$ & $0.60 \pm 0.01 \mathrm{a}$ \\
\hline Concentration $/ \mathrm{ml}\left(\mathrm{x} 10^{6}\right)$ & $442.0 \pm 8.50 \mathrm{~b}$ & $401.0 \pm 5.77 \mathrm{a}$ & $384.0 \pm 5.79 \mathrm{a}$ \\
\hline Semen motility $\quad(\%)$ & $70.81 \pm 0.81 \mathrm{a}$ & $71.59 \pm 1.25 \mathrm{a}$ & $71.18 \pm 0.90 \mathrm{a}$ \\
\hline Live cells & $71.80 \pm 0.67 \mathrm{~b}$ & $81.90 \pm 0.89 \mathrm{a}$ & $84.10 \pm 1.06 \mathrm{a}$ \\
\hline
\end{tabular}

a,b means in the same row followed by the same letter are not signific antly different $(\mathrm{p}>0.05)$.

composition and aspects of metabolism is now being polyunsaturated fatty acids of the n-3 series in asked. With such a high-profile presence of long chain mammalian sperm lipids, it is suggested that the 
alteration of the current fatty acid profile of animal proprietary feeds towards increasing levels of acids of the $n-3$ series may be highly relevant to the ontogeny of the characteristic fatty acid profiles and subsequent function of the sperm (Ducci et al., 2002). The present findings suggests that LNA is a more physiological source of n-3 fatty acids for rabbit and that the increase of spermatozoa kinetics and functional property is obtained without severe depression of antioxidant stability of semen.

\section{CONCLUSIONS}

The inclusion of the Alpha linolenic (18:3, n3) fatty acids (supplemented with $4 \%$ or $6 \%$ extruded flaxseed) in the diet was to increase signific antly their levels within the spermatozoa and to have extensive beneficial effects on parameters of spermatozoa function and therefore male fertility in the New Zealand White rabbit males.

\section{REFFERENCES}

Aitken RJ, Fisher H. (1994). Reactive oxygen species generation and human spermatozoa: the balance of benefit and risk. Bioassays, 16, 259-267.

Aitken RJ, Harkiss D, Buckingham D. (1993). Relationship between iron-catalysed lipid peroxidation potential and human sperm function. J. Reprod. Fertil., 98, 257-265.

AOAC (2015). Official Methods of Analysis. 15th Ed. AOAC, Washington, DC, USA.

Blesbois E, Lessire M, Grasseau I, Hallouis JM, Hermier D. (1997). Effect of dietary fat on the fatty acid composition and fertilizing ability of fowl semen. Biol. Reprod., 56, 1216-1220.

Castellini C, DAL Bosco A, Mugnai C. (2003). Oxidative status and semen characteristics of rabbit males as affected by dietary vitamin $\mathrm{E}, \mathrm{C}$ and $\mathrm{n}-3$ fatty acids. Reprod Nutr. Dev., 43, 41-53.
Comhaire FH, Christophe AB, Zalata AA, Dhooge WS, Mahmoud AMA, Depuydt CE. (2000). The effects of combined conventional treatment, oral antioxidants and essential fatty acids on sperm biology in subfertile men. Prost. Leukotr. Ess. Fatty Acids, $63,159-165$

Conquer JA, Martin JB, Tummon I, Watson L, Tekpetey F (2000). Effect of DHA supplementation on DHA status and sperm motility in asthenozoospermic males. Lipids, 35, 149-154.

DE Blas C, Wiseman J (1998). The nutrition of the rabbit.

Duncan DB (1955). Multiple range and multiple F-test Biometrics, 11:1-42 .

Cabi Oxon UK, Ducci M, Gazzano A, Villani C, Cela V, Artini PG, Martelli F, Genazzani AR (2002). Membrane integrity evaluation in rabbit spermatozoa. Europ. J. Ostetr. Gynec. Repr. Biol., 102, 1, 53-56.

Jones R, Mann T, Sherins $R$ (1979). Peroxidative breakdown of phospholipids in human spermatozoa, spermicidal, properties of fatty acid peroxides, and protective action of seminal plasma. Fertil. Steril., 31, 78-85.

Folch J, Lees M, Sloane-Stanley H. (1957). A simple method for the isolation and purification of total lipids from animal tissues. J. Biol. Chem., 226, 497-502.

Maertens L, Moermans R, DE Groote G. (1984). Prediction of apparent digestible energy content of commercial pelletted feeds for rabbits. J. Appl. Rabbit Res., 11, 60- 67.

Poulos A, Darin-Bennet A, White IG. (1973). The phospholipid-bound fatty acids and aldehydes of mammalian spermatozoa. Comp. Biochem. 46, 541549.

SAS (2011). Statistical Analysis System, User's Guide Version 8.2 Cary NC. USA . 
Baiomy, A.A and H. H. M, Hassanien, 2020

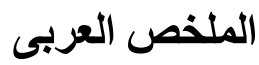 \\ تأثير حض اللينولينيك فى الغذاء على الاداء التناسلى وصفات السائل المنوى فى ذكور الارانب \\ احمد عبد الجليل بيومي 1 ـ حسام حسين محمد حسانين`

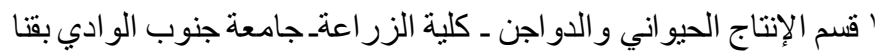

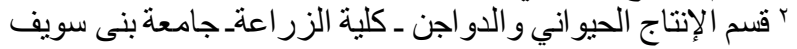

أجريت هذه الدراسة بمزرعة الإنتاج الحيواني كلية الزراعة. جامعة جنوب الوادي بقنا خلال من شهر يناير الى أبريل ـ ا ب لدراسة تأثير

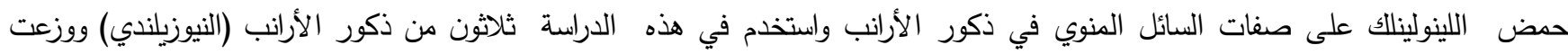

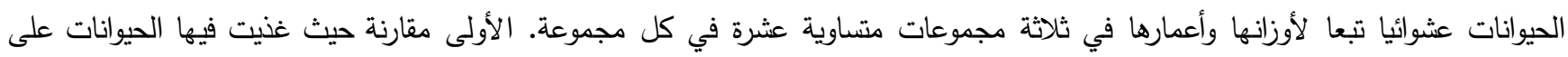

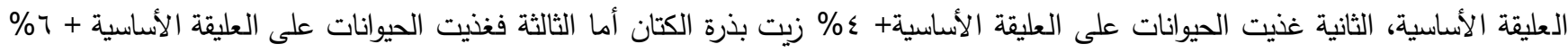

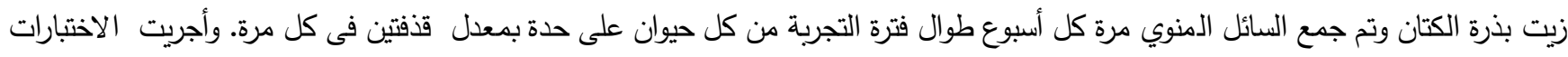

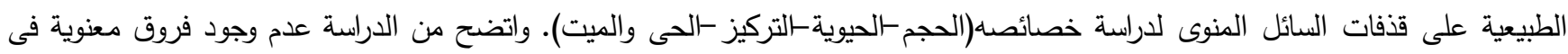

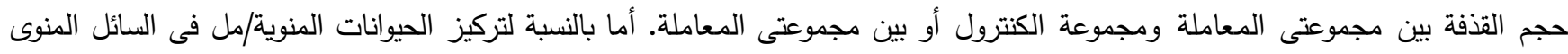

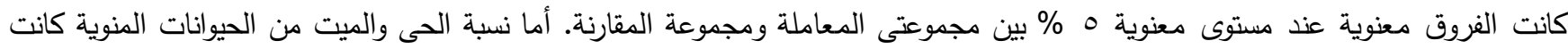

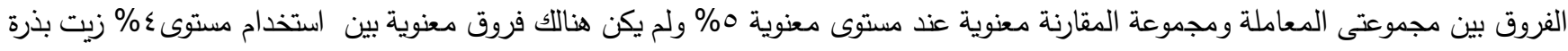
الكتان و \%\% زيت بذرة الكتان ـ من هذه النتائج يتضح أن اضافة زيت بذرة الكتان الى عليقة ذكور الارانب النيوزيلندى ألابيض سواء عنداء

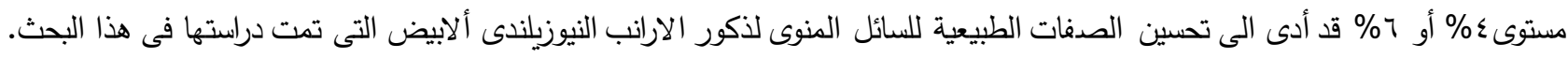

